\title{
Medical negligence and the law
}

\author{
K K S R MURTHY ${ }^{1}$
}

'Faculty member, ICFAI Law School, ICFAI University, Dehradun 248006 INDIA e-mail: sriramakmurthy@rediffmail.com

\begin{abstract}
After the Consumer Protection Act, 1986, came into effect, a number of patients have filed cases against doctors. This article presents a summary of legal decisions related to medical negligence: what constitutes negligence in civil and criminal law, and what is required to prove it.

Public awareness of medical negligence in India is growing. Hospital managements are increasingly facing complaints regarding the facilities, standards of professional competence, and the appropriateness of their therapeutic and diagnostic methods. After the Consumer Protection Act, 1986, has come into force some patients have filed legal cases against doctors, have established that the doctors were negligent in their medical service, and have claimed and received compensation. As a result, a number of legal decisions have been made on what constitutes negligence and what is required to prove it.
\end{abstract}

\section{Civil law and negligence}

Negligence is the breach of a legal duty to care. It means carelessness in a matter in which the law mandates carefulness. A breach of this duty gives a patient the right to initiate action against negligence.

Persons who offer medical advice and treatment implicitly state that they have the skill and knowledge to do so, that they have the skill to decide whether to take a case, to decide the treatment, and to administer that treatment. This is known as an "implied undertaking" on the part of a medical professional. In the case of the State of Haryana vs Smt Santra, the Supreme Court held that every doctor "has a duty to act with a reasonable degree of care and skill" (1).

Doctors in India may be held liable for their services individually or vicariously unless they come within the exceptions specified in the case of Indian Medical Association vs V P Santha (2). Doctors are not liable for their services individually or vicariously if they do not charge fees. Thus free treatment at a non-government hospital, governmental hospital, health centre, dispensary or nursing home would not be considered a "service" as defined in Section 2 (1) (0) of the Consumer Protection Act, 1986.

However, no human being is perfect and even the most renowned specialist could make a mistake in detecting or diagnosing the true nature of a disease. A doctor can be held liable for negligence only if one can prove that she/ he is guilty of a failure that no doctor with ordinary skills would be guilty of if acting with reasonable care (3). An error of judgement constitutes negligence only if a reasonably competent professional with the standard skills that the defendant professes to have, and acting with ordinary care, would not have made the same error (4).

In a key decision on this matter in the case of Dr Laxman Balkrishna Joshi vs Dr Trimbak Bapu Godbole, the Supreme Court held that if a doctor has adopted a practice that is considered "proper" by a reasonable body of medical professionals who are skilled in that particular field, he or she will not be held negligent only because something went wrong.

Doctors must exercise an ordinary degree of skill (5). However, they cannot give a warranty of the perfection of their skill or a guarantee of cure. If the doctor has adopted the right course of treatment, if she/ he is skilled and has worked with a method and manner best suited to the patient, she/ he cannot be blamed for negligence if the patient is not totally cured (6).

Certain conditions must be satisfied before liability can be considered. The person who is accused must have committed an act of omission or commission; this act must have been in breach of the person's duty; and this must have caused harm to the injured person. The complainant must prove the allegation against the doctor by citing the best evidence available in medical science and by presenting expert opinion (7).

In some situations the complainant can invoke the principle of res ispa loquitur or "the thing speaks for itself". In certain circumstances no proof of negligence is required beyond the accident itself. The National Consumer Disputes Redressal Commission applied this principle in Dr Janak Kantimathi Nathan vs Murlidhar Eknath Masane (8).

The principle of res ipsa loquitur comes into operation only when there is proof that the occurrence was unexpected, that the accident could not have happened without negligence and lapses on the part of the doctor, and that the circumstances conclusively show that the doctor and not any other person was negligent.

\section{Criminal negligence}

Section 304A of the Indian Penal Code of 1860 states that whoever causes the death of a person by a rash or negligent 
act not amounting to culpable homicide shall be punished with imprisonment for a term of two years, or with a fine, or with both.

In the Santra case, the Supreme Court has pointed out that liability in civil law is based upon the amount of damages incurred; in criminal law, the amount and degree of negligence is a factor in determining liability. However, certain elements must be established to determine criminal liability in any particular case, the motive of the offence, the magnitude of the offence, and the character of the offender.

In Poonam Verma vs Ashwin Patel the Supreme Court distinguished between negligence, rashness, and recklessness (9). A negligent person is one who inadvertently commits an act of omission and violates a positive duty. A person who is rash knows the consequences but foolishly thinks that they will not occur as a result of her/ his act. A reckless person knows the consequences but does not care whether or not they result from her/ his act. Any conduct falling short of recklessness and deliberate wrongdoing should not be the subject of criminal liability.

Thus a doctor cannot be held criminally responsible for a patient's death unless it is shown that she/ he was negligent or incompetent, with such disregard for the life and safety of his patient that it amounted to a crime against the State (10).

Sections 80 and 88 of the Indian Penal Code contain defences for doctors accused of criminal liability. Under Section 80 (accident in doing a lawful act) nothing is an offence that is done by accident or misfortune and without any criminal intention or knowledge in the doing of a lawful act in a lawful manner by lawful means and with proper care and caution. According to Section 88, a person cannot be accused of an offence if she/ he performs an act in good faith for the other's benefit, does not intend to cause harm even if there is a risk, and the patient has explicitly or implicitly given consent.

\section{Burden of proof and chances of error}

The burden of proof of negligence, carelessness, or insufficiency generally lies with the complainant. The law requires a higher standard of evidence than otherwise, to support an allegation of negligence against a doctor. In cases of medical negligence the patient must establish her/ his claim against the doctor.

In Calcutta Medical Research Institute vs Bimalesh Chatterjee it was held that the onus of proving negligence and the resultant deficiency in service was clearly on the complainant (11). In Kanhaiya Kumar Singh vs Park Medicare \& Research Centre, it was held that negligence has to be established and cannot be presumed (12).

Even after adopting all medical procedures as prescribed, a qualified doctor may commit an error. The National Consumer Disputes Redressal Commission and the Supreme Court have held, in several decisions, that a doctor is not liable for negligence or medical deficiency if some wrong is caused in her/ his treatment or in her/ his diagnosis if she/ he has acted in accordance with the practice accepted as proper by a reasonable body of medical professionals skilled in that particular art, though the result may be wrong. In various kinds of medical and surgical treatment, the likelihood of an accident leading to death cannot be ruled out. It is implied that a patient willingly takes such a risk as part of the doctor-patient relationship and the attendant mutual trust.

\section{Recent Supreme Court rulings}

Before the case of Jacob Mathew vs State of Punjab, the Supreme Court of India delivered two different opinions on doctors' liability. In Mohanan vs Prabha G Nair and another (13), it ruled that a doctor's negligence could be ascertained only by scanning the material and expert evidence that might be presented during a trial. In Suresh Gupta's case in August 2004 the standard of negligence that had to be proved to fix a doctor's or surgeon's criminal liability was set at "gross negligence" or "recklessness."

In Suresh Gupta's case the Supreme Court distinguished between an error of judgement and culpable negligence. It held that criminal prosecution of doctors without adequate medical opinion pointing to their guilt would do great disservice to the community. A doctor cannot be tried for culpable or criminal negligence in all cases of medical mishaps or misfortunes.

A doctor may be liable in a civil case for negligence but mere carelessness or want of due attention and skill cannot be described as so reckless or grossly negligent as to make her/ him criminally liable. The courts held that this distinction was necessary so that the hazards of medical professionals being exposed to civil liability may not unreasonably extend to criminal liability and expose them to the risk of imprisonment for alleged criminal negligence.

Hence the complaint against the doctor must show negligence or rashness of such a degree as to indicate a mental state that can be described as totally apathetic towards the patient. Such gross negligence alone is punishable.

On September 9, 2004, Justices Arijit Pasayat and CK Thakker referred the question of medical negligence to a larger Bench of the Supreme Court. They observed that words such as "gross", "reckless", "competence", and "indifference" did not occur anywhere in the definition of "negligence" under Section 304A of the Indian Penal Code and hence they could not agree with the judgement delivered in the case of Dr Suresh Gupta.

The issue was decided in the Supreme Court in the case of Jacob Mathew vs State of Punjab (14). The court directed the central government to frame guidelines to save doctors from unnecessary harassment and undue pressure in performing their duties. It ruled that until the government framed such guidelines, the following guidelines would prevail:

A private complaint of rashness or negligence against a doctor may not be entertained without prima facie evidence in the form of a credible opinion of another competent 
doctor supporting the charge. In addition, the investigating officer should give an independent opinion, preferably of a government doctor. Finally, a doctor may be arrested only if the investigating officer believes that she/ he would not be available for prosecution unless arrested.

\section{References}

1. State of Haryana vs. Smt. Santra (2000) 5 SCC 182:: AIR 2000 SC 3335

2. Indian Medical Association vs V P Santha. AIR 1996 SC 550

3. Observations of Lord President Clyde in Hunter vs Hanley (1955) SLT 213. In: Nathan HL. Medical Negligence. London: Butterworths; 1957.

4. Whitehouse vs. Jordan (1981) 1 All ER 267 the House of Lords.

5. Smt J S Paul vs Dr (Mrs) A Barkataki (2004) 10 CLD 1 (SCDRC MEGHALAYA).

6. Dr Prem Luthra vs Iftekhar (2004) 11 CLD 37 (SCDRC - UTTARANCHAL);
Mrs Savitri Devi vs Union of India IV (2003) CPJ 164; Dr Devendra Madan vs Shakuntala Devi I (2003) CPJ 57 (NC).

7. Dr Laxman Balkrishna Joshi vs Dr Trimbak Bapu Godbole AIR 1969 (SC) 128

8. Dr Janak Kantimathi Nathan vs Murlidhar Eknath Masane 2002 (2) CPR 138.

9. Poonam Verma vs Ashwin Patel (1996) 4 SCC 332

10. House of Lords decision in R vs Adomako (1994) 3 All ER 79

11. Calcutta Medical Research Institute vs Bimalesh Chatterjee I (1999) CPJ 13 (NC)

12. Kanhaiya Kumar Singh vs Park Medicare \& Research Centre III (1999) CPJ 9 (NC)

13. Mohanan vs Prabha G Nair and another (2004) CPJ 21(SC), of 2004 Feb 4.

14. Criminal Appeal Nos $144-145$ of 2004

\section{If you are looking for India's finest medical journal, then here it is.}

The National Medical Journal of India is a premier bi-monthly multi-disciplinary health sciences journal which publishes original research, reviews, and other articles relevant to the practice of medicine in India. The journal aims to instruct, inform, entertain and provide a forum for the discussion of social, economic and political health issues. It is included in the Index Medicus (Pubmed), Excerpta Medica (EmBase), BIOSIS, Current Contents/Clinical Medicine and Science Citation Index.

\section{SUBSCRIPTIONS}

$\begin{array}{lllll} & \text { One year } & \text { Two years } & \text { Three years } & \text { Five years } \\ \text { Indian } & \text { Rs } 600 & \text { Rs } 1100 & \text { Rs } 1600 & \text { Rs } 2600 \\ \text { Overseas } & \text { US } \$ 85 & \text { US } \$ 150 & \text { US } \$ 220 & \text { US } \$ 365\end{array}$

Personal subscriptions paid from personal funds are available at $50 \%$ discounted rates

Cheques/Demand Drafts should be made payable to The National Medical Journal of India. Please add Rs 75 for outstation cheques.

If you wish to receive the Journal by registered post, please add Rs 90 per annum to the total payment and make the request at the time of subscribing.

Please send all renewals and new subscriptions along with the payment to:

The Subscription Department, The National Medical Journal of India, All India Institute of Medical Sciences, Ansari Nagar, New Delhi 110 029. Tel:91-11-2658-8802 Fax:91-11-2658-8663 E-mail:nmji@nmji.in Website:www.nmji.in

The National Medical Journal of India

On the frontline of Indian medicine 